\title{
Analysis of the impact of training on the performance of Small and Medium-sized enterprises in Northwest Mexico, by applying the Structural Equations Statistical Technique (SEM-PLS)
}

María del Carmen Vásquez-Torres, Ph.D.,

Technological Institute of Sonora in the Department of Administrative

Sciences, Mexico, ORCID: 0000-0003-0938-4955.

Arturo Tavizón Salazar, Ph.D., Universidad Autónoma de Nuevo León, México,

Facultad de Contaduría Pública y Administración, ORCID: 0000-0003-4463-7276.

José Guadalupe Flores López, Ph.D.,

Technological Institute of Sonora in the Department of Administrative

Sciences, Mexico, ORCID: 0000-0002-6380-5135.
Publication funded with resources from the Research Promotion and Support Program (PROFAPI)

\section{Introduction}

Since the appearance of the first theories of the organizations, the training has always been fundamental in this rich literature to illustrate its importance in the development of the company; in addition, it is essential to generate greater efficiency not only in the SMEs, but also in the employees and to increase the productivity of the organizations. Currently, at a global level, the importance of training has been increasing due to consumer demand and competition; this is why, it is a necessity for companies and workers since it is reflected in performance and, consequently, in customer satisfaction.

Various studies demonstrate that intellectual capital directly influences competitive 
performance, where knowledge management is fundamental since it directly affects superior performance; however, intellectual capital is sometimes not reflected in financial performance, but in value creation (Lynn, 1988, cited in Estrada, 2007). In this sense, economically measuring knowledge and intangible resources will always represent difficulties. As can be appreciated, if this is not easy for the big company, it will be even more of a challenge for the SME; but knowing how to capitalize on, it will provide a competitive advantage.

Llerena (2019) mentions that job satisfaction has a positive influence on employees' performance and organization. The study indicates that there is a high significant correlation, where satisfaction showed the weakest relationship with the economic aspect. In this order of ideas, Robbins and Judge (2009) indicate that workers' performance is directly related to their satisfaction and the wellbeing in the organization.

Training is something that in one way or another has always been present, everywhere. Romero (2010) mentions that the industrial revolution that took place in Europe at the end of the 18th century caused several changes in the commercial sphere and in social structures; and thus, modifying the existing training method. From then on, personnel with little experience could be working with machinery, so it had consequences, the unions began to decline. Later, when the manufacturing process replaced the domestic process, it assimilated the apprentices causing a new type of teaching, where the owner of the machinery was also the owner of the factory and the apprentice, and after the training period, would become a worker.

During the 18th century, training programs arrived in the United States, but they were not as successful as in Europe because the immigrants had experience in the work. In the case of Mexico, after the industrial development, there was the construction of factories and with it the need to train and capacitate the personnel at different levels, with the intention of increasing effectiveness (Romero, 2010). Today, training is a fundamental aspect in all organizations that want to succeed and be among the expectations of their customers.

Yang and Yang (2010) mention that the majority of private organizations in China, do not consider an important factor the training and coaching programs, which creates a problem for all companies. In addition, Reynoso (2007) mentions that in Latin America in recent years, there has been a great deal of controversy with government, private sector and union executives in different countries, about training policies and organizational approaches that are forging the growth of training institutions and policies, from which lessons are learned and new approaches are deployed. 
Latin American training systems have differently developed from a common basic model to coordinate the acquisition and use of skills by the workforce; moreover, currently resulting in underperforming training systems with little capacity for innovation. In some countries the training system that has been developed is capable of experimentation and innovation in the provision of training services. Although some countries have positive training systems, there is an idea that their performance is inefficient and their products are not significant in terms of the required skills; thus, generating little impact on wages and the employment capacity of a sector of the region's population (Reynoso, 2007).

Gary (2009) believes that if staff is properly trained, they will have the needed knowledge and skills to perform their jobs efficiently, since the goal of training is to teach new skills. The article 153-A of the Federal Labor Law, mentions that the employers have the responsibility to provide the qualification and training to all workers that facilitate them to have a better standard of living. Furthermore, the above must be offered during the employee's working hours, unless both parties agree that it could be offered in another manner or at another location. Finally, it should aim to provide knowledge to entry-level employees and to those who are interested in filling another available position or vacancy.

Dessler and Varela (2011) comment that training currently covers many areas beyond employment. Previously, it was focused on operational activities, as in the implementation of a tactical activity; nevertheless, these are processes that lead to the completion of functions. Due to the evolution of technology, now it is not enough to train them in these areas, but also to use the equipment that helps companies to have greater productivity such as machinery and computer equipment.

Pedraza, Amaya and Conde (2010) from the University of Zulia, Colombia, conducted a study in order to know if job stability influenced the performance of workers. They say that the certainty of staying at work contributes positively to performance and is evident in the productivity results; so it is considered that the detected dissatisfaction in workers is due to the lack of stability and adequate remuneration by the organization to employees.

One of the factors that stand out is the dissatisfaction with the way of gratification, which was considered to be the main factor influencing job performance. Employees consider that it could improve their performance if there is an improvement change in their hiring and fees.

Ramirez (2004) considers that the level of training is reflected in the employee performance. Being adequately prepared will be reflected in a good performance, 
so it is recommended to train staff several times a year with the intention of improving performance, motivating professional development and increasing the employee knowledge.

The obligation of employers to train their workers has existed for more than four decades, but the level of compliance is still low. By the end of 2012, only $68 \%$ of the subscribed employers with the Mexican Social Security Institute (formal sector of the economy), had registered compliance with their legal obligations regarding training and education with the Ministry of Labor and Social Welfare (STPS, 2013).

According to Sapién, Piñón and Gutiérrez (2014), although there are companies that make significant efforts to train employees in Mexico, there is still a long way to go. There is no awareness of the fact that organizations have systematic training plans and programs in accordance with the demands of these times of constant change. All companies should have a joint commission for training and education, as well as plans and programs duly registered with the Ministry of Labor and Social Prevention (STPS); in addition, they should assign a unique and exclusive annual budget for training and education, which would formalize training in companies and would help to create a culture of annual training among employees.

The training of personnel is of great importance within organizations; the performance of workers depends largely on it, but sometimes it results in little contribution and positive response to the needs of the company, which has generated a large number of problems that affect the operation and performance of human capital. According to Chiavenato (2011), there are training problems, such as: absenteeism, changes in work methods, reduction of personnel, personnel movements, modernization of equipment or work processes, new products, lower performance, etc.

Despite all the indicated benefits, there are companies that do not consider staff training an important factor, which generates a problem for them, reflecting in low utility in the organization by lack of knowledge or updating employees. There are also problems associated with the innovation management and productive improvement due to inadequate or non-existent training of its human talent; that is why it is pointed out that as long as an organization has good training, it improves knowledge of the work area and contributes to the development of leaders and managers in the business (Mejía, Montoya \& Vélez, 2010).

It is necessary to implement constant education, training and the adequate monitoring, so that it is permanently enriched, generates the best possible results and contributes to the productive and competitive improvement of SMEs 
(Ramirez, Diaz \& Rodriguez, 2009). It is important to note that only an adequate business strategy can help as a guide to ensure that the actions to be taken before, during and after the training are in line with this alignment.

As a result of the above, the following question arises: How does training impact the organizational performance of SMEs in northwestern Mexico?

Globalization and a vertiginous scientific-technical development impose complex change processes and continuous social transformations; it increases the cognitive needs of human capital to respond to new demands in their professional performance; and that at the same time, imposes greater demands on their training (Salgado, Gomez, \& Carvajal, 2017). To increase the competitiveness of an organization, the workforce must be rather informed, adaptable and competent. Intellectual capital (IC) is no less important, than capital investments for businesses (Chen, Cheng and Hwang, 2005). Agreeing with Salazar (2009), it is essential to focus on human capital, which is why he proposes that it is necessary to have a training model that collaborates in achieving better performance by employees.

Guerrero \& Galindo (2014) mention that when providing training, multiple benefits for the company and for the person to whom it is directed are obtained; in addition, there is achieved an increase in profitability with active employees who improve their skills and increase their productivity with higher quality results.

In this sense, Dessler (2009) considers that training is the root of timely and profitable management, which is why, it mentions that managers should have the responsibility not to dismiss it since having human capital with a high level of potential, properly directed, can be successful in the organization; however, if they do not have the willingness, they will hardly contribute to the company.

\section{Objective:}

To analyze the impact of training on the organizational performance of SMEs in northwestern Mexico, applying the statistical technique of structural equations (SEM-PLS).

Ha: Training has an effect on the performance of SMEs in northwestern Mexico.

\section{Literature Review}

Training is part of the education of people, which includes learning and generates new ways of doing things and new knowledge. These changes must be 
the result of a need first diagnosed, similarly, Pinto (2005) stresses the importance of making profound changes in the company's processes, especially in production processes that respond to the demands of competitiveness in the global market; working hard on technology, a solid administration and human resources that will allow the organization to have a high organizational performance. This is why it is so relevant, since in addition to contributing their effort and knowledge, they will have an attitude towards the continuous improvement of total quality.

Chiavenato (2011) mentions that the training cycle involves four stages: detection of training needs (diagnosis); training program to meet the needs; implementation and realization of the training program; and finally, evaluation of the results. Although each stage is named differently, it can be seen that they are very similar to those proposed by Pinto (2005).

Ivancevich (2005) considers training as a structured process, linked to the employees' behavior and in order to meet the company's goals. Training is connected to current job skills and competencies. It consists of induction and helps to master the particular skills required to be successful.

Table 1 shows the training process recommended by different authors.

Table 1. Training Process

\begin{tabular}{|c|c|}
\hline Author & Training Process \\
\hline Bohlander \& Snell (2009) & $\begin{array}{l}\text { 1. Needs assessment. } \\
\text { 2. Design of programs. } \\
\text { 3. Implementation of the training program } \\
\text { 4. Training Program Evaluation }\end{array}$ \\
\hline Pinto (2005) & $\begin{array}{l}\text { 1. Planning } \\
\text { 2. Organization } \\
\text { 3. Execution } \\
\text { 4. Evaluation }\end{array}$ \\
\hline Gary (2009). & $\begin{array}{l}\text { 1. Analysis of training needs } \\
\text { 2. Instructional Design } \\
\text { 3. Validation } \\
\text { 4. Implementation of the program } \\
\text { 5. Evaluation }\end{array}$ \\
\hline Dessler \& Varela (2011) & $\begin{array}{l}\text { 1. Needs assessment } \\
\text { 2. Didactic design } \\
\text { 3. Validation } \\
\text { 4. Implementation } \\
\text { 5. Evaluation }\end{array}$ \\
\hline
\end{tabular}




\begin{tabular}{l|l} 
Grados (2009) & $\begin{array}{l}\text { 1. Planning } \\
\text { Training needs assessment (TNA) } \\
\text { Objective setting } \\
\text { Plans and programs setting } \\
\text { 2. Organization } \\
\text { Structure and systems } \\
\text { Integration of people } \\
\text { Integration of material resources } \\
\text { Training of internal instructors } \\
\text { 3. Implementation } \\
\text { Instructional materials and supports } \\
\text { Hiring services } \\
\text { Course coordination } \\
\text { 4. Evaluation and monitoring } \\
\text { About the system } \\
\text { About the instructional process } \\
\text { The monitoring is to evaluate the activities }\end{array}$ \\
\hline Chiavenato (2011) & $\begin{array}{l}\text { 1. Training needs assessment (diagnosis) } \\
\text { 2. Training program to meet the needs. } \\
\text { 3. Implementation and execution of the training program } \\
\text { 4. Evaluation of the results }\end{array}$ \\
\hline
\end{tabular}

Source: own elaboration

In this sense, it can be stated that training is fundamental in the dynamics of the organization, since it is one of the ways to generate radical changes to increase the company's productivity, opening the way to international markets.

Performance is behavior and results taken as a whole. Performance is simply what people do and what happens as a result of what they do (McAdams, 2013). Performance refers to the employee's behaviors or actions that are under review and affect the organization's goals (Rotundo \& Sackett, 2002).

For companies to be successful, it is necessary to consider effective tools to increase performance, a key factor in the success of entrepreneurship and can be achieved through personal qualities. Some qualities are common among businessmen and need to be actively applied, since these are very important in the success of their business. Other qualities may be natural or incorporated in their individual character such as: innovative personality, risk taking, confidence, commitment to do things and decision making are discussed (De Araújo \& Lopes, 2014). 
According to Terán and Ireland (2011), performance has focused on unidimensional (quantitative) and multidimensional (quantitative and qualitative) measures. In order to consider a broader and not only economic approach, the multidimensional approach will be used as it encompasses the qualitative (efficiency and effectiveness) and quantitative aspect (Camisón \& Cruz, 2008; Calderón-Hernández \& Naranjo-Valencia, 2010; Cheung, Wong \& Lam; 2012; Cantillo, 2013).

For Bernardez (2009), the performance in the organization will be integrated by strategy, including clear standards and marketing plans; management, related to organizational management, quality of supervision, leadership and motivation; processes, which has to be adequate, with defined methods, and there is planning and programming of these methods; feedback, that it is timely and practical, from top to bottom and vice versa, including customers and users; finances, involving administrative, purchasing and budgeting systems; and technology, information systems, collaboration, hardware and software are considered.

According to Cheung, Wong and Lam (2012), the elements to consider in organizational performance are finance, internal business processes, customers, and innovation and learning. Camisón and Cruz (2008, p. 88) define organizational performance "as a multidimensional construct, with four correlated elements: financial results, operational efficiency, stakeholder satisfaction and ability to compete". Financial results refer to economic and financial profitability, sales, sales growth (domestic, international), market growth, solvency and financial liquidity. Operational efficiency consists of everything related to labor productivity and cost efficiency. Stakeholder satisfaction includes customer satisfaction, employee satisfaction, wealth generation and image. Ability to compete is about the position in the local, national and international market, competitive position in prices and quality.

Table 2. Elements of Organizational Performance

\begin{tabular}{l|l}
\hline Author & Elements of Organizational performance \\
\hline Cheung, Wong \& Lam (2012) & 1. Finances \\
& 2. Internal business processes \\
& 3. Clients \\
& 4. Innovation and learning
\end{tabular}




\begin{tabular}{|c|c|}
\hline Bernardez (2009) & $\begin{array}{l}\text { 1. Strategy } \\
\text { 2. Management } \\
\text { 3. Finances } \\
\text { 4. Processes } \\
\text { 5. Feedback } \\
\text { 6. Technology }\end{array}$ \\
\hline Camisón \& Cruz (2008 & $\begin{array}{l}\text { 1. Financial results } \\
\text { 2. Operational efficiency } \\
\text { 3. Stakeholders satisfaction } \\
\text { 4. Ability to compete }\end{array}$ \\
\hline
\end{tabular}

Source: own elaboration

\section{Methodology}

In this research it was used a methodology that was quantitative, descriptive, correlational and causal; furthermore, it was used a statistical technique of structural equations model (SEM) with the SMART PLS 3.3.2 software with a non-experimental cross-sectional design, in the year 2020. Moreover, none of the proposed variables were manipulated, as established by Hernandez, Fernandez, and Baptista (2010). The information was collected through the application of a sample in one of the northwestern states of Mexico. It was a probabilistic convenience sample, through the application of a measuring instrument that was sent to 318 companies; $61 \%$ of which responded, being 195 companies, in a single moment, which is called cross-sectional. The probabilistic sample has a reliability of $95 \%$ according to Hernández, Fernández, and Baptista (2010), with a simple random sample calculation. The instrument was used to collect, process and analyze the training and performance variables in SMEs in the three sectors (commercial, industrial and services) of Ciudad Obregon, Sonora, located in northwestern Mexico; consequently, the information is quantitative.

\section{Subjects}

The participants in the research were small and medium enterprises from Ciudad Obregon, Sonora, Mexico from various sectors, according to information obtained from the database of the National Institute of Statistics and Geography (INEGI 2009) in its National Statistical Directory of Economic Units (DENUE). The instruments were applied to SMEs, small companies with 11-30 employees and medium companies with 31-100 employees in Ciudad Obregon, Sonora, 
Mexico. A total of 55 service companies, 67 commercial and 73 industrial companies participated, giving a number of 195 companies surveyed. It was considered a probabilistic and convenient sample.

The companies that have been in the market for 1 to 5 years represent $13.8 \%$; from 6 to 10 years for $24.6 \%$; from 11 to 15 years account for $10.8 \%$; and, from 16 to 20 years for $10.8 \%$. As for the seniority of the managers, it was obtained that 1 to 5 years represent $50.3 \%$; and from 6 to 10 years, $27.2 \%$. A total of $39 \%$ of company managers are women and $61 \%$ are men (see table 3 ).

Table 3. Characteristics of the individuals participating in the study $(n=195)$

\begin{tabular}{|c|c|c|c|c|}
\hline & Frequency & Percentage & $\begin{array}{c}\text { Valid } \\
\text { Percentage }\end{array}$ & $\begin{array}{l}\text { Accumulative } \\
\text { Percentage }\end{array}$ \\
\hline \multicolumn{5}{|l|}{ Line of business } \\
\hline Service & 55 & 28.2 & 28.2 & 28.2 \\
\hline Trading & 67 & 34.4 & 34.4 & 62.6 \\
\hline Industrial & 73 & 37.4 & 37.4 & 100.0 \\
\hline Total & 195 & 100.0 & 100.0 & \\
\hline \multicolumn{5}{|l|}{ Manager's gender } \\
\hline Female & 76 & 39.0 & 39.0 & 39.0 \\
\hline Male & 119 & 61.0 & 61.0 & 100.0 \\
\hline Total & 195 & 100.0 & 100.0 & \\
\hline \multicolumn{5}{|c|}{ Seniority of the company } \\
\hline 1 to 5 years & 27 & 13.8 & 13.8 & 13.8 \\
\hline 6 to 10 years & 48 & 24.6 & 24.6 & 38.4 \\
\hline 11 to 15 years & 21 & 10.8 & 10.8 & 49.2 \\
\hline 16 to 20 years & 21 & 10.8 & 10.8 & 60 \\
\hline 21 to 25 years & 15 & 7.7 & 7.7 & 67.7 \\
\hline 26 to 30 years & 21 & 10.8 & 10.8 & 78.5 \\
\hline 31 to 35 years & 11 & 5.6 & 5.6 & 84.1 \\
\hline
\end{tabular}




\begin{tabular}{l|r|r|r|r}
\hline 36 to 40 years & 12 & 6.2 & 6.2 & 90.3 \\
\hline 41 years and older & 19 & 9.7 & 9.7 & 100 \\
\hline \multicolumn{1}{c|}{ Total } & 195 & 100.0 & 100.0 & \\
\hline Seniority in management position & & & & \\
\hline 1 to 5 years & 98 & 50.3 & 50.3 & 50.3 \\
\hline 6 to 10 years & 53 & 27.2 & 27.2 & 77.5 \\
\hline 11 to 15 years & 13 & 6.7 & 6.7 & 84.2 \\
\hline 16 to 20 years & 18 & 9.2 & 9.2 & 93.4 \\
\hline 21 to 25 years & 6 & 3 & 3 & 96.4 \\
\hline 26 years and older & 7 & 3.6 & 3.6 & 100 \\
\hline \multicolumn{1}{c|}{ Total } & 195 & 100.0 & 100.0 & \\
\hline
\end{tabular}

Source: own elaboration

\section{Materials}

A tool was developed for application to SMEs in the industrial, commercial and service sector. The characteristics of the instrument are the following: general information (name of the company, seniority of the company, line of business, number of employees (men and women), name of the manager, sex, seniority in the position, level of education, relationship with the owners, and if she/he has previously owned another company.

The design of the instrument was based on Pinto (2005) in terms of training, with a total of 31 items; in terms of performance, it was developed in accordance with Bernárdez (2009) with 34 items, having a total of 65 questions.

The mediating variable of training has 5 independent variables (planning, organization, execution, evaluation, benefit) and the dependent variable of organizational performance influenced by 6 independent variables (strategy, management, processes, feedback, finance and technology), as shown in the cause-effect diagram below (figure 1). 


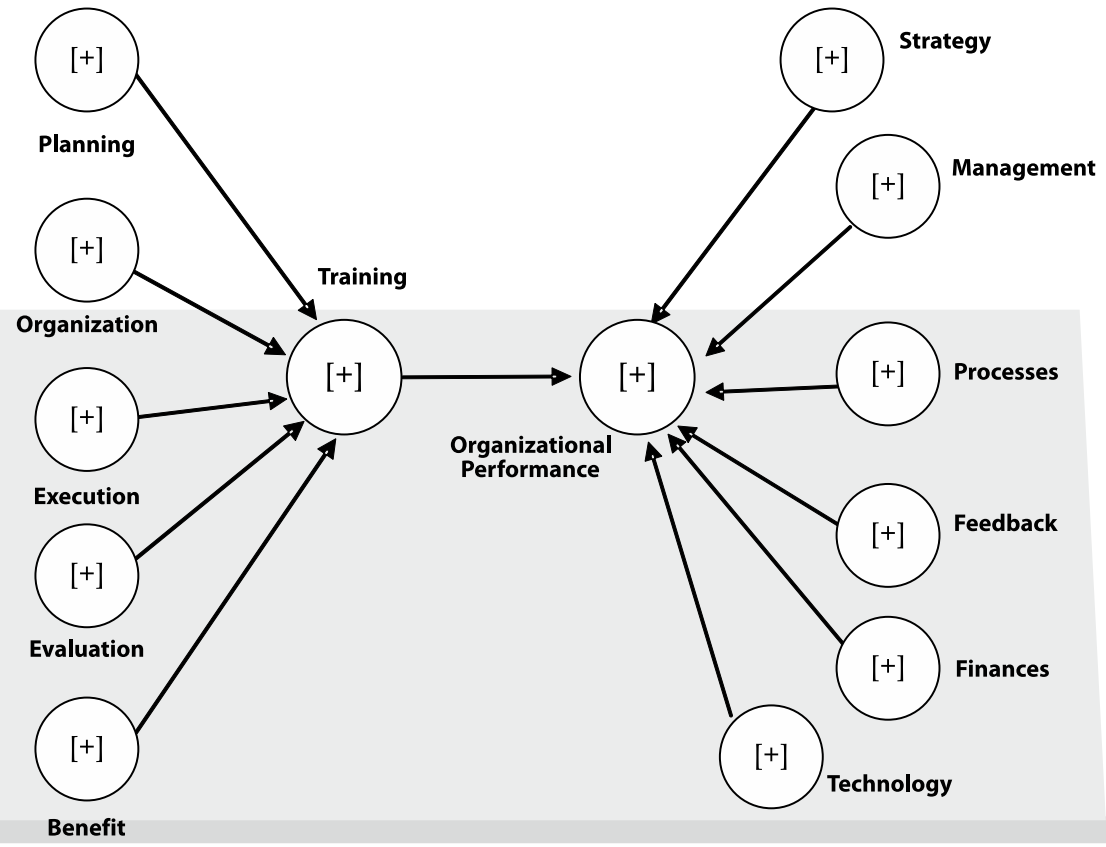

Figure 1. Cause-effect diagram

Source: own elaboration

Table 4 shows the operationalization of the variables. The instrument has a 5-point Likert scale.

Table 4. Operationalization of the variables

\begin{tabular}{l|l|l}
\hline \multicolumn{1}{c|}{ Elements } & \multicolumn{1}{|c}{ Description } & Items \\
\hline Training & $\begin{array}{l}\text { Training of people includes learning, resulting in new ways of doing } \\
\text { things and new knowledge; these changes must be the result of a firstly } \\
\text { diagnosed need (Pinto, 2005). }\end{array}$ & 6 items \\
\hline Planning & $\begin{array}{l}\text { It is the phase that gives sense and technical content to the training, } \\
\text { since it leads to determine what is going to be done. }\end{array}$ & 6 items \\
\hline Organization & $\begin{array}{l}\text { It is the phase where the training system is sustained to achieve the } \\
\text { behavioral changes established in the objectives, and to eliminate the } \\
\text { detected problems in the planning phase. }\end{array}$ & 4 items \\
\hline
\end{tabular}




\begin{tabular}{l|l|l}
\hline Execution & $\begin{array}{l}\text { It is the setting of the training process, involving interests, time, and } \\
\text { efforts of all employees; as well as the tools and form of communication, } \\
\text { to ensure that what is being done is according to plan. }\end{array}$ & 6 items \\
\hline Evaluation & $\begin{array}{l}\text { It is to measure and correct all the interventions to ensure that the } \\
\text { actions are in accordance with the established plans. It is to compare } \\
\text { what has been done with what has been planned. }\end{array}$ & 6 items \\
\hline Benefit & $\begin{array}{l}\text { All the elements or factors that have a positive impact when receiving } \\
\text { training. }\end{array}$ & 3 items \\
\hline $\begin{array}{l}\text { Organizational } \\
\text { Performance }\end{array}$ & $\begin{array}{l}\text { Employee behaviors or actions that are under their review and affect } \\
\text { the organization's goals (Rotundo \& Sackett, 2002). }\end{array}$ & 7 items \\
\hline Strategy & The company establishes objectives and marketing plans. & 5 items \\
\hline Management & $\begin{array}{l}\text { The company provides quality supervision, leadership and motivation } \\
\text { to its employees. }\end{array}$ & 3 items \\
\hline Processes & Correct processes; defined methods, planning and programming. & 7 items \\
\hline Feedback & $\begin{array}{l}\text { Feedback is timely and accurate, given from top to bottom, as well as } \\
\text { from customers and users. }\end{array}$ & 4 items \\
\hline Finances & Budgeting system, purchasing and administrative system. & 4 items \\
\hline Technology & Information systems, collaboration systems, hardware and software & 4 items \\
\hline
\end{tabular}

Source: own elaboration

Regarding the reliability of the instrument, the Cronbach's Alpha statistic of the mediating variable training is 0.809 . For the independent variables are: planning 0.884 ; organization 0.847 ; execution 0.801 ; evaluation 0.876 ; profit 0.809 ; strategy 0.836; management 0.606 ; processes 0.934 ; feedback 0.859 ; finances 0.835 ; technology 0.787 .

Cronbach's alpha for the dependent variable organizational performance was 0.820 . As can be seen, the coefficients range from 0.934 to 0.606 , which indicates an acceptable internal consistency according to Martínez, Hernández and Hernández (2006), who indicate that it is satisfactory above 0.60 (see table 5).

According to the authors Hair, Ringle, and Sarstedt (2011), the average variance extracted (AVE) must be greater than 0.5 for the convergent validity of the reflective measurement model, allowing two indicators of reliability and internal validity of the constructs (table 5). 
Table 5. Reliability and internal validity of constructs

\begin{tabular}{l|c|c}
\hline Latent Variables/Dimension & Cronbach's Alpha & $\begin{array}{c}\text { Average Variance } \\
\text { Extracted (AVE) }\end{array}$ \\
\hline Training & 0.809 & 0.522 \\
\hline Planning & 0.884 & 0.633 \\
\hline Organization & 0.847 & 0.688 \\
\hline Execution & 0.801 & 0.514 \\
\hline Evaluation & 0.876 & 0.669 \\
\hline Benefit & 0.809 & 0.724 \\
\hline Organizational Performance & 0.820 & 0.530 \\
\hline Strategy & 0.836 & 0.606 \\
\hline Management & 0.606 & 0.554 \\
\hline Processes & 0.934 & 0.716 \\
\hline Feedback & 0.859 & 0.705 \\
\hline Finances & 0.835 & 0.671 \\
\hline Technology & 0.787 & 0.614 \\
\hline
\end{tabular}

Source: own elaboration

\section{Procedure}

It was developed the research background, definition of the problem, objective, research based in IEGI's database about the studied companies, instrument according to the research guideline; in addition, the approval of the instrument by experts in the field, and the pilot test application, obtaining an acceptable Cronbach's Alpha-in the independent, mediating and dependent variables. The remaining questionnaires were then applied, using the SMART PLS 3.3.2 to process them, obtaining the results and conclusions.

\section{Results}

The results obtained for the analysis of the impact of training on the performance of small and medium-sized enterprises in Mexico, applying structural equations model (SEM-PLS), are presented below. 
The $\mathrm{R}^{2}$ coefficient of determination represents the explanation of the variability of the dependent variable through the causality of the independent and mediating constructs. In this model, there are two coefficients of determination for the moderator variable training and the dependent variable organizational performance. $\mathrm{R}^{2}$ for training presents 0.832 and for Organizational performance 0.860 , see table 6 .

Table 6. $\mathbf{R}^{2}$ and Adjusted $\mathbf{R}^{2}$

\begin{tabular}{l|c|c}
\hline Variables & $\mathrm{R}^{2}$ & Adjusted $\mathbf{R}^{2}$ \\
\hline Training & 0.832 & 0.827 \\
\hline Organizational Performance & 0.860 & 0.854 \\
\hline
\end{tabular}

Source: own elaboration

The following cause and effect model shows the values of the t-statistic between the independent variables and the dependent variable of organizational performance. With this test, the significance and reliability levels of the most important causal relationships can be verified. Evaluation, execution, feedback, managwement, planning, processes, and training stand out with a reliability of $95 \%$, with values greater than 2.0 ; and with a reliability of $90 \%$ for the variables of profit and organization and with t-values of less than 2.0. In the same way, the causalities and significances of the variables finance, strategy and technology are rejected for having $\mathrm{t}$-values lower than 1.0, being these not significant. See figure $2 \mathrm{t}$-statistic. 


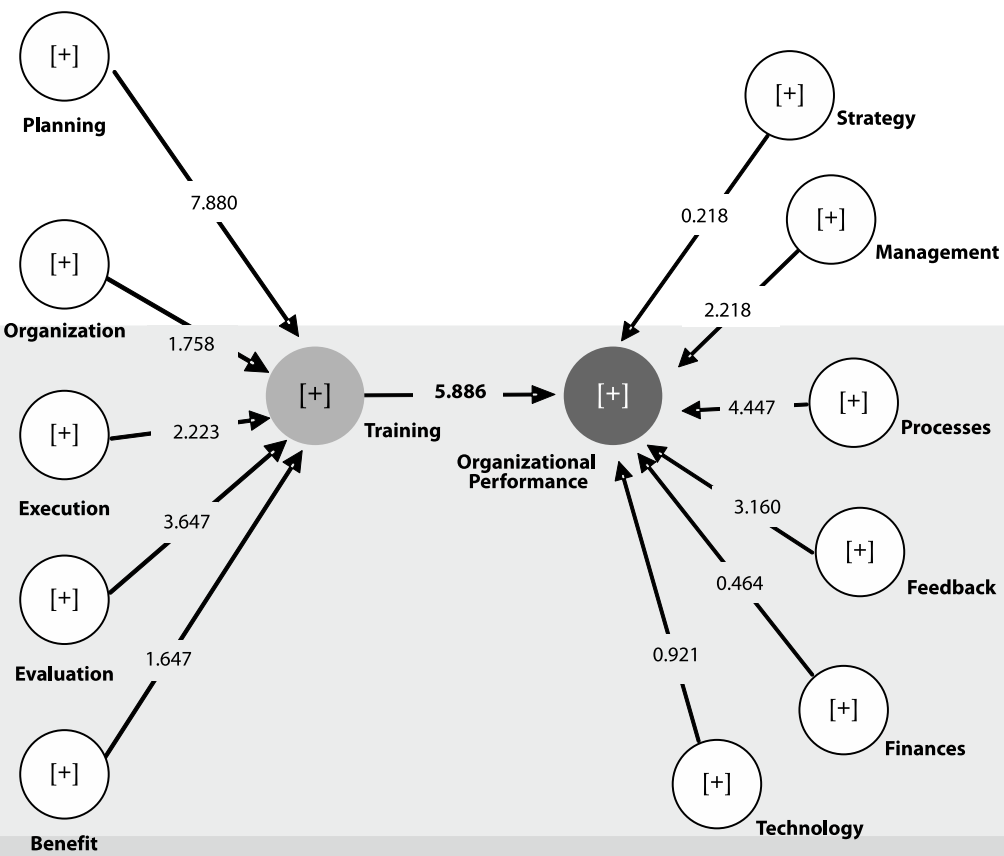

Figure 2. T-statistic

Source: own elaboration

Table 7. Training and Performance Betas

\begin{tabular}{l|c|c|c|c|c}
\hline Latent Variables & $\begin{array}{c}\text { Training } \\
\boldsymbol{\beta}\end{array}$ & $\begin{array}{c}\text { Organizational } \\
\text { Performance } \\
\boldsymbol{\beta}\end{array}$ & $\mathbf{t}$ & P value & VIF \\
\hline $\begin{array}{l}\text { Training (CA) -> Organizational } \\
\text { Performance }\end{array}$ & \multicolumn{2}{|c|}{0.453} & 5.886 & 0.000 & 3.524 \\
\hline Planning (CP) & 0.499 & & 7.880 & 0.000 & 3.295 \\
\hline Organization (CO) & 0.093 & & 1.758 & 0.079 & 2.708 \\
\hline Execution (CEj) & 0.128 & & 2.223 & 0.027 & 2.369 \\
\hline Evaluation (CEv) & 0.231 & & 3.647 & 0.000 & 3.059 \\
\hline
\end{tabular}




\begin{tabular}{l|c|c|c|c|c}
\hline Benefit (CB) & 0.078 & & 1.647 & 0.100 & 1.660 \\
\hline Strategy (DE) & & 0.011 & .218 & 0.828 & 2.370 \\
\hline Management (DM) & & 0.092 & 2.218 & 0.027 & 1.748 \\
\hline Processes (DP) & & 0.327 & 4.447 & 0.000 & 2.838 \\
\hline Feedback (DR) & & 0.223 & 3.16 & 0.002 & 2.012 \\
\hline Finances (DF) & & -0.020 & .464 & 0.643 & 1.323 \\
\hline Technology (DT) & & -0.034 & .921 & 0.358 & 1.475 \\
\hline
\end{tabular}

Source: own elaboration

The alternative hypothesis is accepted as shown in table 7.

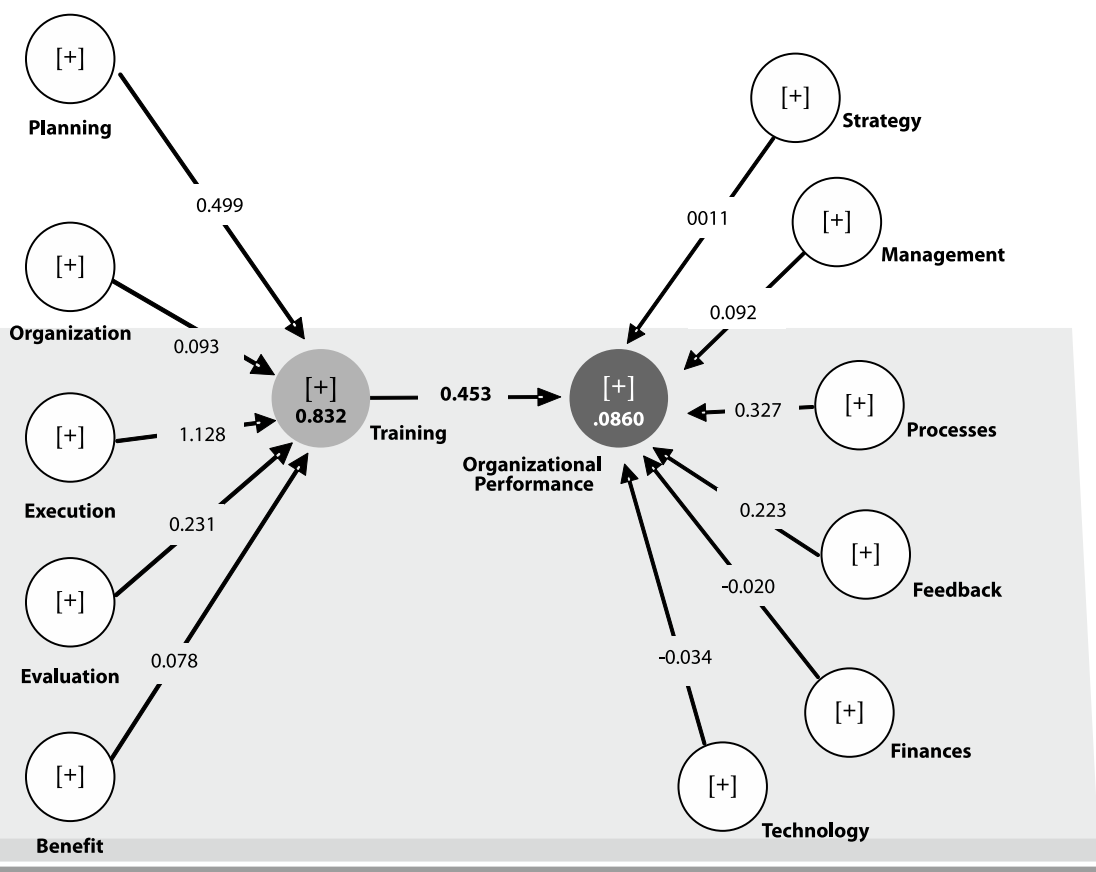

Figure 3. Betas and R2 coefficients of Training and Organizational Performance Source: own elaboration 
Ha: Training has an effect on the organizational performance of the northwestern SMEs. It is highly significant with 0.000 , of the P value, i.e. there is very strong evidence of causality of the mediating variable training towards the organizational performance of the SMEs with 99.9\% reliability.

- $99 \%$ reliability= Training, planning, evaluation, processes

- 95\% reliability= Execution, Management, Feedback

- $90 \%$ reliability= Organization, Benefit

For the development of the structural equations, they are constructed from the results of the significant coefficients betas in the quality tests of the model, resulting in the two equations shown below:

\section{Structural Equations of the Predictive Model}

\section{Equation 1}

\section{Training $=0.499 \mathrm{CP}+0.093 \mathrm{CO}+0.128 \mathrm{CEj}+0.231 \mathrm{CEv}+0.078 \mathrm{CB}$}

To predict the training modeling variable, five independent variables with a positive causal effect on training were identified, which are planning (PC), organization (OC), execution (CEj), evaluation (CEV) and benefit (BC). The variables with the greatest effect on training are planning, followed by evaluation and execution, with a small effect on organization and benefit.

\section{Equation 2}

Organizational Performance $=0.453 \mathrm{CA}+0.011 \mathrm{DE}+0.092 \mathrm{DM}+0.327 \mathrm{DP}+$ 0.223 DR -0.020 DF -0.034 DT

The equation for organizational performance contemplates seven independent variables which include the moderating variable of training, being this the most important with positive effects, followed by processes (PD), and feedback (RD); with less positive effect in strategy (DE) and Management (DM), with a small and inverse effect the variables of finance (DF) and technology (DT).

\section{Discussion}

Training is a tool that helps in the education of personnel by developing their skills and knowledge within an organization. Over time, many authors have studied this concept; Servitje (2008), Chiavenato (2002) and Invancevich (2005) determine that training is a form of teaching and learning for staff, providing them with necessary skills, abilities, and attitudes to better perform their activities. This indicates that training and performance have a relationship when 
delivering training to staff and when evaluating performance. Article153-A of the Federal Labor Law states that employers are responsible for providing training to their employees.

Yang and Yang (2010) mention that the majority of private organizations do not consider training and coaching programs as an important factor; however, based on the obtained results in the research; it shows that companies do consider it important to have training programs since they generate greater benefits, as can be seen with the ones studied in the commercial area. López and Luna (2009) detected in their research that entrepreneurs perceived that training generates costs for them. In order to avoid any misperceptions, it is essential for company leaders to have a formalized training process, as can be seen in the results. It is the planning stage that will have the greatest impact on the organization's performance.

According to Ramirez (2004), training is reflected in the employee's performance is fully proven in the study.

\section{Conclusions}

The objective of analyzing the training impact on the organizational performance of SMEs in northwestern Mexico, applying the structural equations model statistical technique (SEM-PLS) is satisfactorily fulfilled. This is due to the verification of the model and its two structural equations in which training shows a positive effect with a high degree of evidence on the organizational performance of the analyzed SMEs.

\section{Equation 1}

Training $=0.499 \mathrm{CP}+0.128 \mathrm{CEj}+0.231 \mathrm{CEv}$

\section{Equation 2}

Organizational Performance $=0.453 \mathrm{CA}+0.092 \mathrm{DM}+0.327 \mathrm{DP}+0.223 \mathrm{DR}$

\section{Equation of general organizational performance}

$0.453(0.499 \mathrm{CP}+0.128 \mathrm{CEj}+0.231 \mathrm{CEv})+0.092 \mathrm{DM}+0.327 \mathrm{DP}+0.223 \mathrm{DR}$

Training has the greatest effect on organizational performance because each unit that increases training will have an effect of +0.453 , being the variable with the greatest cause-effect impact on organizational performance in SMEs in northwestern Mexico. 
The importance of the training variable is its level of mediation in the variables of planning, execution and evaluations, so that these together have a greater effect on organizational performance, and thus obtain an improvement in the SMEs in the area. Execution and evaluation are two variables that together contribute a third more effect on training and organizational development; therefore SMEs believe that proper planning with effective execution and constant evaluation contributes 0.8 more to training to make it successful, and it impacts almost $45 \%$ more on the organizational performance of SMEs.

SMEs consider that the financial and technological aspects diminish organizational performance by fully complying with these two variables in their processes and utilization, respectively, but the effects are not significant and there is little evidence that they affect organizational performance. In the other hand, the organization variable does not have a significant impact at $95 \%$, but it does have a $90 \%$ impact on training, because the process of organizing training should be considered important within the model, but it should be studied in the future to corroborate the evidence and its significance on training and organizational performance.

The importance of the training variable has been proven, since it is a need of the companies to have prepared personnel, being a key factor to generate a greater competitive advantage impacting in the performance of the company, especially in the processes. Having trained workers generates great benefits to the organizations among them greater productivity, increases the effectiveness of staff, higher performance and the human factor feels more secure at the time of carrying out their activities.

Nowadays, training is no longer considered a secondary activity; it has become a very important factor for the achievement of competitiveness strategies of companies. Companies that provide training have a greater benefit in the effective performance of their personnel, in aspects such as economy, saving of raw materials, less defective products, among others, by properly attending to the processes and providing feedback. It also helps in the administrative aspect, in the way they realize outstanding employees, optimal development and greater commitment to it.

\section{Summary}

Analysis of the impact of training on the performance of Small and Medium-sized enterprises in Northwest Mexico, by applying the Structural Equations Statistical Technique (SEM-PLS)

Small and medium enterprises (SMEs) are fundamental to the economy of all countries, representing the majority, with 
a considerable contribution to GDP, as well as generating jobs; for this reason, it must seek to remain in the market. The objective is to analyze the impact of training on the organizational performance of SMEs in northwestern Mexico, applying the statistical technique of structural equations model (SEM-PLS); the research was conducted to 195, considering the commercial, industrial and services, is a quantitative study, descriptive, correlational, causal, using the statistical technique of structural equations with the SMART PLS 3.3.2 software, and not experimental cross-sectional. The alternative hypothesis is accepted, since training has an effect on the organizational performance of SMEs in northwestern Mexico. It is highly significant because there is very strong evidence of the causality of the mediating variable training on the organizational performance of SMEs with $99.9 \%$ reliability. Training has the greatest effect on organizational performance because each unit that increases training will have an effect of +0.453 , being the variable with the greatest cause-effect impact on organizational performance in SMEs in northwestern Mexico.

Keywords: Training, Performance, Organization, SME, development.

\section{JEL}

Classification: M53, L25, M12

\section{References}

Bermúdez, L. A. (2014). Necesidades de capacitación de las Pymes del Cantón de Bagaces. Reflexiones, 93 (2), pp. 11-21, Universidad de Costa Rica San José, Costa Rica.

Bernárdez, M. L. (2007). Desempeño Organizacional. Conceptos y Herramientas para la Mejora, creación e incubación de nuevas organizaciones. GLOBAL BUSINESS PRESS.

Bernárdez, M.L. (2009). Desempeño Humano Manual de consultoría Volumen I. GLOBAL BUSINESS PRESS. Versión digital. Reproducido con expresa autorización del autor para exclusivo uso en el Instituto para la Mejora del Desempeño de ITSON.

Calderón-Hernández, G., \& Naranjo-Valencia, J. C. (2010). Estrategia competitiva y desempeño organizacional en empresas industriales Colombianas. INNOVAR. Revista de Ciencias Administrativas y Sociales, 20(38), 13-26. 
Camisón, Z. C., \& Ros, S. C. (2008). La medición del desempeño organizativo desde una perspectiva estratégica: creación de un instrumento de medida. Revista europea de dirección y economía de la empresa, 17(1), 79-102.

Cantillo, P. J. C. (2013). Incidencia de la cultura organizacional en el desempeño. Revista Económicas CUC, Vol. 34, No. 1, pp. 131-152.

Cejas, M. \& Acosta, J. (2012). La capacitación laboral: Alcances y perspectivas en tiempos complejos. Anuario, Vol. 35.

Chen, M. C., Cheng, S. J., \& Hwang, Y. (2005). An empirical investigation of the relationship between intellectual capital and firms' market value and financial performance. Journal of Intellectual Capital, 6(2), 159-176. http:/ /dx.doi.org/10.1108/14691930510592771

Cheung, S. O., Wong, P. S., \& Lam, A. L. (2012). An investigation of the relationship between organizational culture and the performance of construction organizations. Journal of Business Economics and Management, 13(4), 688-704.

Chiavenato, I. (2011). Administración de Recursos Humanos, el capital de las organizaciones. Novena Edición. Editorial McGraw Hill.

De Araújo, M. S. G., \& Lopes, P. M. P. R. (2014). Virtuous leadership, organizational commitment and individual performance. Tékhne, 12 (1). http:/ / dx.doi.org/10.1016/j.tekhne.2015.01.008

Dessler, G. \& Varela R. (2011) Administración de recursos humanos, Enfoque latinoamericano. Quinta edición. Pearson.

Dessler, G. (2009). Administración de Recursos Humanos. Decimoprimera edición. Pearson Educacion, México.

Estrada, S., \& Dutrénit, G. (2007). Gestión del conocimiento en pymes y desempeño competitivo. Engevista, 9(2), pp. 129-148.

Gary, D. (2009). Administración de recursos humanos.Décima primera edición. PEARSON EDUCACIÓN.

Grados, E.J. (2009). Capacitación y desarrollo de personal. Cuarta edición, México: Trillas.

Guerrero, J., \& Galindo J. (2014). Administración 2. Grupo Editorial Patria. México.

Hair, J. F., Ringle, C. M. y Sarstedt, M. (2011). PLS-SEM: INDEED A SILVER BULLET (De hecho, una bala de plata). Journal of Marketing Theory and Practice, 19 (2), 139-152.

INEGI, (2009). Instituto Nacional de Estadística y Geografía. “Micro, pequeña, mediana y gran empresa: estratificación de los establecimientos: Censos Económicos 2009",

Ivancevich, J. (2005). Administración de recursos humanos. Novena Edición. Editorial McGraw Hill.

Ley Federal del Trabajo. (Coordinación Trueba, U. A. \& Trueba, B. J.) Ley Federal del Trabajo. Comentarios, Prontuario, Jurisprudencia y Bibliografía. 88 edición. México D.F. Porrúa. 
Llerena, N. A. B. (2019). Satisfacción laboral y su relación con el desempeño laboral en una Pyme de servicios de seguridad en el Perú. Journal of Economics Finance and International Business, 3(1), 75-103.

Martínez, M. R., Hernández, M. J., \& Hernández, M. V. (2006). Psicometría. Madrid, España: Alianza Editorial, S. A.

McAdams J. (2013). Premiar el desempeño: Una guía del directivo para mejorar los resultados a través de las personas. Madrid, España: Ediciones Díaz de Santos.

Pedraza, E., Amaya, G., \& Conde, M. (septiembre-diciembre, 2010). Desempeño laboral y estabilidad del personal administrativo contratado de la Facultad de Medicina de la Universidad del Zulia. Revista de Ciencias Sociales (Ve), vol. XV, (pp. 493-505).

Pinto, V. R. (1997). Proceso de capacitación. (Tercera edición). Editorial Diana Pinto, R. 2005. Planeación estratégica de capacitación empresarial. Mc Graw Hill

Ramírez A. (2004), Capacitación y desempeño laboral de los empleados de la universidad Linda Vista de la Unión Mexicana de Chiapas (Tesis de maestraia). Universidad de Montemorelos, Chiapas.

Reynoso, C. C. (2007). Notas sobre la capacitación en México. Revista Latinoamericana de Derecho Social, núm. 5, 165-190.

Romero, K. (2010). La capacitación y la motivación como herramientas para conseguir una ventaja competitiva. Licenciatura. Universidad veracruzana.

Robbins, S., \& Judge, T. (2009). Comportamiento organizacional. Decimotercera edición. México: Editorial Pearson Educación.

Rotundo, M. y Sackett, P. (2002). The Relative Importance of Task, Citizenship, and Comunterproductive Performance to Global Ratings of Job Performance: A Policy-Capturing Approach. Journal of Applied Psychology, 87(1), pp. 66-80. doi:10.1037//0021-9010.87.1.66

Salazar, R. (2009) Propuesta de un modelo de capacitación para mejorar el desempeño del capital humano en la empresa Flimex, S.A. de C.V. Instituto Politécnico Nacional, Tlalpan Cd. De México.

Salgado, M., Gómez O., \& Carvajal, D. T. (2017). Niveles para la capacitación en una organización. Ingeniería Industrial, 38(2), 154-160.

Sapién Aguilar, A. L., Piñón Howlet, L. C. \& Gutiérrez Díez, M. d. C. (2014). Capacitación en la empresa mexicana: un estudio de formación en el trabajo. Civilizar. Ciencias Sociales y Humanas, 14(27) 123-134. http:// www.redalyc.org/articulo.oa?id=100235716007

Secretaria del trabajo y previsión social (2013). Acuerdo 301204. http:// www.stps.gob. $\mathrm{mx} / \mathrm{bp} /$ secciones/conoce/marco_juridico/archivos/ acuerdo301204.pdf 
Terán, V. O. E. \& Irlanda, J. L. (2011). Influencia de la cultura organizacional en el desempeño laboral y la productividad de los trabajadores administrativos en instituciones de educación superior. Omnia, 17(1), 96110.

Villavicencio, J. M. (2006). Factores críticos para el desempeño exportador de las Pymes. Tec Empresarial, 1(1), pág. 32-37.

Yang, H., \& Yang, X. (2010). Research on enhancing the effectiveness of staff-training in private enterprise. iBusiness, 2, 92-97. doi:10.4236/ ib.2010.21011 